\title{
MANAJEMEN PENINGKATAN MUTU PEMBELAJARAN BAHASA INGGRIS BERBASIS PROJECT BASED LEARNING (PBL) DI SMA NEGERI 1 CICALENGKA
}

\section{PROJECT BASED LEARNING (PBL) BASED ENGLISH LANGUAGE LEARNING QUALITY IMPROVEMENT MANAGEMENT AT SMA NEGERI 1 CICALENGKA}

\author{
Nining Diningsih \\ e-mail : Niningdiningsih11@gmail.com \\ SMA Negeri 1 Cicalengka Bandung \\ Tati Suminar \\ e-mail : tati_suminar@gmail.com \\ MA Al Falah Cianjur \\ Ricky Yoseptr \\ e-mail : rickyyoseptry01@gmail.com \\ UIN Sunan Gunung Djati Bandung \\ Rita Sulastin \\ e-mail : ritasulastini60@gmail.com \\ UIN Sunan Gunung Djati Bandung
}

\begin{abstract}
Abstrak
Yang melatarbelakangi penelitian ini adalah Masalah proses pembelajaran Bahasa Inggris dalam meningkatkan mutu pembelajaram ( Studi Kasus Tentang Speaking di SMA Negeri 1 Cicalengka dan SMA Negeri Cikancung Kabupaten Bandung ) proses pembelajaran Bahasa Inggris selama ini cenderung terpusat pada guru, umumnya guru menyampaikan pembelajaran di kelas dengan metode konvensional dan berdasarkan hasil wawancara dengan guru Bahasa Inggris aspek Speaking Skill tidak mencapai Kriteria Ketuntasan sehingga berpengaruh terhadap kualitas pembelajaran Bahasa Inggris. Pembelajaran Bahasa Inggris tidak terlepas dari peran manajemen pembelajaran dimana guru merencanakan, melaksanakan dan mengevaluasi berbagai tindakan yang dilakukan dalam melaksanakan kegiatan pembelajaran termasuk memanfaatkan berbagai media dan metode pembelajaran yang memudahkan siswa dalam mencapai tujuan pembelajaran terutama belajar Bahasa Inggris pada Aspek Speaking. Untuk mengatasi hal tersebut yang dapat dilakukan guru adalah menyiapkan pembelajaran dengan menerapkan manajemen pembelajaran. Tujuan penelitian ini adalah untuk mengetahui tentang perencanaan pembelajaran menggunakan metode Project Learning dalam meningkatkan aspek speaking merekomendasikan bahwa metode Project Learning dapat menjadi satu dari metode pembelajaran pilihan dan menerapkannya untuk meningkatkan berbicara Bahasa Inggris siswa.
\end{abstract}

Kata kunci: Manajemen, Mutu Pembelajaran, PBL 


\begin{abstract}
Behind this research is the problem of the English learning process in improving the quality of learners (Case Study On Speaking at Sma Negeri 1 Cicalengka and Sma Negeri Cikancung Bandung Regency) the english learning process has tended to be centered on teachers, generally teachers convey learning in the classroom with conventional methods and based on the results of interviews with English teachers aspects of Speaking Skill do not reach the Criteria of Completion so far. It has no effect on the quality of English learning. English learning is inseparable from the role of learning management where teachers plan, implement and evaluate various actions carried out in carrying out learning activities including utilizing various media and learning methods that make it easier for students to achieve learning goals, especially learning English on speaking aspects. To overcome this, what teachers can do is prepare learning by applying learning management. The aim of this study is to find out about learning planning using Project Learning methods in improving the speaking aspect recommending that the Project Learning method can be one of the preferred learning methods and apply it to improve students' English speaking.
\end{abstract}

Keywords: Management, Learning Quality, PBL

Submitted : 11-11-2021 | Accepted : 20-12-2021 | Published : 26-12-2021

\title{
PENDAHULUAN
}

Berdasarkan Undang-Undang Republik Indonesia Nomor 20 Tahun 2003 Tentang Sistem Pendidikan Nasional, disebutkan bahwa Pendidikan Nasional berfungsi mengembangkan kemampuan dan membentuk watak serta peradaban bangsa yang bermartabat dalam rangka mencerdaskan kehidupan bangsa. Pendidikan Nasional bertujuan untuk mengembangkan potensi peserta didik agar menjadi manusia yang beriman dan bertaqwa kepda Tuhan ang Maha Esa.

Dijelaskan pula bahwa pendidikan diselenggarakan secara demokratis dan berkeadilan serta tidak diskriminatif dengan menjunjung tinggi hak asasi, nilai keagamaan, kultural dan kemajuan bangsa. Pendidikan diselenggarakan sebagai satu kesatuan yang sistematik dengan sistem terbuka dan multi makna.

Sekolah merupakan lembaga pendidikan yang memiliki peran yang penting untuk meningkatkan kemampuan berbahasa Inggris bagi peserta didik. Karena sekolah merupakan suatu sistem yang komponen-komponen di dalamnya terintegrasi dengan baik. Sedangkan mata pelajaran bahasa Inggris itu sendiri merupakan mata pelajaran yang bersifat adapatif, yang bertujuan untuk membekali peserta didik dengan kemampuan berkomunikasi menggunakan bahasa Inggris baik dalam konteks material komunikasi, yang sangat 
diperlukan baik program keahliannya, dalam bentuk lisan maupun tulisan. Selain itu pelajaran bahasa Inggris pun membekali peserta didik kemampuan berkomunikasi dalam kehidupan sehari-hari, yang sesuai dengan tuntutan global, dan secara langsung pelajaran bahasa Inggris juga telah membekali peserta didik untuk mengembangkan komunikasi ke taraf yang lebih tinggi. Artinya dengan penguasaan bahasa Inggris perseta didik memilik alat pengembangan diri dalam bidang ilmu penegtahuan, tekhonologi, seni dan budaya.

Karena beringinan dengan adanya suatu perubahan era, contoh konkretnya seperti halnya revolusi industri yang seiringan perubahan zaman serta era akan mempengaruhi aspek kehidupan umat manusia, mulai dari munculnya kemampuan serta keterampilan baru, dan teknologi baru. Sehingga para generasi muda haruslah dibekali dengan kemampuan serta wawasan yang suatu saat hal tersebut akan membantu mereka untuk hidup di era globalisasi ini. Akan tetapi banyak masyarakat menilai bahwasannya metode Project Based Learning hanya diperuntukan untuk mereka yang akan bekerja di bidang sains dan tekhnologi saja. Padahal penerapannya dalam bahasa Inggris pun sangatlah diperlukan karena pada era ini kegiatan industri serta kegiatan perekonomian negara Indonesia tidak hanya bergerak dalam pasar domestik saja akan tetapi bergerak dalam pasar skala internasional. Pada era globalisasi ini bahasa Inggris dipilih sebagai bahasa bisnis secara Internasional untuk mencapai kesepakatan bisnis. Sehingga dengan memeiliki kemampuan komunikasi dalam bahasa Inggris yang baik dinilai akan memudahkan mereka terutama para pelaku bisnis maupun politikus, selain itu bahasa Inggris pun memiliki peran sentral dalam perkembangan intelektual dan emosional peserta didik dan merupakan penunjang keberhasilan dalam mempelajari berbagai macam bidang studi termasuk bahasa Inggris. Pembelajaran bahasa Inggris diharapkan dapat membantu mereka dalam bersaing baik dalam skala nasional maupun internasional.

Berdasarkan masalah penelitian yang akan dikaji oleh peneliti, perumusan masalah penelitian akan disesuaikan dengan sejauh mana manajemen pembelajaran dengan menggunakan metode Project Base Learning dalam meningkatkan keterampilan bicara bahasa Inggris speaking kelas di SMAN 1 Cicalengka dan SMAN Cikancung. Beberapa metode dalam pembelajaran bahasa Inggris mulai dari cara menulis procedur text, yang ditujukan agar peserta didik mampu mendeskripsikan serta memberikan arahan dalam bahasa Inggris, 
sehingga peserta didik mampu mengenal dan menggunakan diksi yang dirasa tepat dalam menjabarkan suatu tatacara dalam melaksanakan ataupun menciptakan suatu produk tertentu.

Tujuan umum dalam penelitian ini adalah untuk memperoleh gambaran serta informasi terkait majemen pembelajaran menggunakan metode Project Based Learning dalam meningkatkan kemampuan speaking pada siswa di SMAN 1 Cicalengka dan SMAN Cikancung.

Peneliti melakukan studi pustaka mengenai perangkat pembelajaran, melakukan observasi sera melakukan penelitian awal melalui melalui pretest dari video untuk mengadakan pendekatan terhadap materi yang akan diajarkan, penjelasannya persiklus, siklus 1 diberikan tes sebelum pakai media dan siklus 2 diberikan tes Speaking untuk menggali potensi di era digital memakai media, dan tahap 1 dilakukan untuk mengukur sejauh mana kemampuan yang dimiliki siswa, refleksi dan pendekatan terhadap materi Speaking di siklus 2. Diberikan tes lagi tentang Speaking untuk menggali potensi dan menanggulangi masalah dan kebutuhan sesuai bahan ajar yang sudah dirancang dalam perangkat pembelajaran.

\section{METODOLOGI}

Penelitian ini diarahkan untuk mendeskripsikan dan menganalisis data temuan secara mendalam tentang masalah manajemen pembelajaran Bahasa Inggris dengan menggunakan metode project based learning dalam meningkatkan kemampuan speaking. Peneliti menggunakan metode penelitian deskriptif dengan pendekatan kualitatif. Data penelitian ini, akan dikumpulkan di SMAN 1 Cicalengka yang berlokasi di Jalan H. Darham No. 42, Desa Babakan Peuteuy, Kecamatan Cicalengka dan SMAN Cikancung Kabupaten Bandung. Melalui pendekatan ini, peneliti berusaha memahami, menafsirkan dan mendeskripsikan kinerja guru Bahasa Inggris dalam kegiatan pembelajaran sehari-hari. Oleh karena itu diperlukannya gambaran secara mendalam tentang manajemen pembelajran Bahasa Inggris khususnya di tingkat sekolah menegah atas dengan menggunakan metode project based learning.

Peneliti menggunakan pendekatan kualitatif karena ingin mengetahui kondisi dan 
gambaran secara alami tentang pelaksanaan pembelajaran Bahasa Inggris di SMAN 1 Cicalengka dan SMAN Cikancung. Terlebih sekolah tersebut adalah tempat peneliti bekerja sehingga diharapkan peneliti dapat mampu menjelaskan atau medeskripsikan objek penelitian dengan baik. Dalam pembelajaran Bahasa Inggris di kelas XI. Sekolah tersebut berdasarkan dari informasi terkait maupun berdasarkan epistumologi peneliti sebagai pengajar di sana mgetahui adanya suatu penerapan metode pembelajaran project based learning, dalam kegiatan pembelajaran bidang studi Bahasa Inggris terkhususnya di kelas XI. Peneliti ingin menjelaskan serta mengetahui lebih dalam mengenai progres serta proses penerapan metode Project Based Learning terkhususnya dalam pembelajaran Bahasa Inggris di sekolah menengah atas tersebut dalam upaya meningkatkan keterampilan speaking siswa.

Penelitian kualitatif mengharuskan peneliti memasuki lapangan untuk mengumpulkan data melaalui observasi. Sebagai Human Instrument peneliti lebih peka dan dapat bereaksi terhadap stimulus dari lingkungan, peneliti dapat menyesuakan diri dengan data yang masuk dan berinteraksi dengan sumber data. Selain itu dapat segera menafsirkannya dan membentuk kesimpulan. Penelitian kualitatif menginginkan data sebanyak mungkin. Ketika komponen dalam situasi sosial (tempat, pelaku, dan kegiatan) dapat diuraikan lebih lanjut untuk memperkaya ruang lingkup pengamatan. Untuk mendapatkan data yang relevan diperlukan teknik pengumpulan data yang tepat. Dalam penelitian ini digunakan beberapa teknik pengumpulan data: observasi, wawancara, dan studi dokumen.

Penelitian kualitatif pada umumnya dapat dibedakan menjadi tiga tahap seperti yang dikemukakan oleh Nasution (2006:33) sebagai berikut “Secara garis besar penelitian kualitatif dapat dibedakan atas tiga tahap yaitu tahap orientasi, eksplorasi dan member check).

\section{HASIL DAN PEMBAHASAN}

Ada teori-teori yang digunakan dalam penelitian ini adalah:

1. Teori Manajemen Pembelajaran

Manajemen pembelajaran berasal dari dua kata yaitu manajemen dan pembelajaran. Kata manajemen berasal dari bahasa latin manus yang berarti tangan dan agree yang berarti 
melakukan. Manager diterjemahkan ke bahasa inggris dalam bentuk kata kerja to manage dengan kata benda management dan diterjemahkan lagi ke bahasa Indonesia menjadi manajemen atau pengelolaan (Husain Usman, 2006:3). Sufyarman mengutip dari Stoner bahwa "manajemen adalah proses proses perencanaan, pengorganisasian, kepemimpinan dan pengendalian, atau upaya anggota organisasi dan penggunaan sumberdaya organisasi untuk mencapai suatu tujuan yang telah ditetapkan di dalam organisasi secara efektif dan efisien" (Sufyarman, 2004: 188-189).

Kesuksesan suatu proses belajar mengajar pada suatu satuan pendidikan dipengaruhi oleh manajemen pembelajaran yang dilaksanakan oleh kepala sekolah dan para tenaga pendidik. Selain itu manajemen pembelajaran juga memiliki peranan penting di setiap satuan pendidikan sebab manajemen pembelajaran menenetukan kualitas lulusan yang menjadi suatu hasil nyata suatu satuan pendidikan telah melaksanakan proses pembelajarannya dengan baik atau tidak. Adapun menurut beberapa ahli seperti (Alben Ambarita, 2006: 72) yang mengemukakan bahwasannya manajemen pembelajaran dapat memiliki arti sebagai suatu kemampuan seorang guru dalam mendayagunakan sumberdaya yang ada, melalui kegiatan menciptakan dan mengembangkan kerja sama, sehingga terbentuk pembelajaran yang mampu mencapai atau memenuhi tujuan pendidikan secara efektif dan efisien.

2. Strategi dan Metode Pembelajaran

Mintzberg dan Waters (1998:87) mengemukakan bahwa strategi adalah pola umum tentang keputusan, atau tindakan (strategies are realized as a pattern in stream of decision or actions). Kemudian Hardy, Langley, dan Rose pun menegemukakan dalam Sudjana (1983:14) strategy is perceived as a plan or a set of explicit intention preceeding and controlling actions. Dalam bahasa Indonesia, strategi dipahami sebagai rencana atau kehendak yang mendahulukan dan mengontrol suatu tindakan.

Berdasarkan beberapa definisi terkait dengan pengertian strategi di atas, dapat ditarik suatu kesimpulan bahwasannya, strategi dapat dikatakan sebagai suatu pola atau rencana yang ditetapkan secara sengaja untuk melakukan kegiatan atau tindakan. Strategi dalam pembelajaran mencakup tujuan kegiatan pembelajaran, mulai dari siapa saja yang terlibat dalam suatu kegiatan pembelajaran, isi dari kegiatan pembelajaran, proses kegiatan 
pembelajaran, dan sarana penunjang kegiatan pembelajaran.

Secara etimologi, metode berasal dari kata metode yang berarti suatu cara kerja yang sistematis untuk memudahkan pelaksanaan kegiatan pembelajaran dalam mencapai suatu tujuan. Metode pembelajaran diartikan sebagai suatu prinsip yang mendasari.kegiatan, mengarahkan perkembangan seseorang khususnya dalam pada proses pembelajaran. metode pembelajaran digunakan oleh guru untuk menyampaikan materi pembelajaran kepada siswa. "Metode pembelajaran dapat diartikan sebagai cara yang dipergunakan oleh guru dalam mengadakan hubungan dengan siswa pada saat berlangsungnya pengajaran ( Nasih, 2009:29). Dengan demikian, metode pembelajaran merupakan alatuntuk menciptakan proses pembelajaran.

Metode pembelajaran yang mampu mengaktifkan siswa, biasanya disusun berdasarkan berbagai teori dan prinsip. Metode pembelajaran berdasarkan prinsip-prinsip pembelajaran, teori-teori psikologis, sosiologis, analisis sistem, atau teori-tori yang mendukung (Joyce dan Weil, 1980).

\section{Metode Pembelajaran PBL}

Pembelajaran Berbasis Proyek Project Based Learning adalah metode pembelajaran yang menggunakan proyek/kegiatan sebagai media. Peserta didik melakukan eksplorasi, penilaian, interpretasi, sintesis, dan informasi untuk menghasilkan berbagai bentuk hasil belajar. Project based learning atau pembelajaran berbasis proyek merupakan model pembelajaran yang berpusat pada siswa untuk melakukan suatu investigasi yang mendalam terhadap suatu topik. Siswa secara konstruktif melakukan pendalaman pembelajaran dengan pendekatan berbasis riset terhadap permasalahan dan pertanyaan yang berbobot, nyata, dan relevan.

Project Based Learning memiliki karakteristik yang membedakan model yang lain. Karakteristik tersebut, antara lain: a) Centrality, Pada project based learning proyek menjadi pusat dalam pembelajaran; b) Driving question, Project based learning difokuskan pada pertanyaan atau masalah yang mengarahkan siswa untuk mencari solusi dengan konsep atau prinsip ilmu pengetahuan yang sesuai; c) Constructive Investigation, Pada project based learning, siswa membangun pengetahuannya dengan melakukan investigasi secara mandiri (guru sebagai fasilitator); d) Autonomy Project based learning menuntut student centered, 
siswa sebagai problem solver dari masalah yang dibahas; dan Realisme Kegiatan siswa difokuskan pada pekerjaan yang serupa dengan situasi yang sebenarnya. Aktifitas ini mengintegrasikan tugas otentik dan menghasilkan sikap profesional.

Adapun tujuan project based learning, antara lain : a) Meningkatkan kemampuan peserta didik dalam pemecahan masalah proyek; b) Memperoleh pengetahuan dan keterampilan baru dalam pembelajaran; c) Membuat peserta didik lebih aktif dalam memecahkan masalah proyek yang kompleks dengan hasil produk nyata; d) Mengembangkan dan meningkatkan keterampilan peserta didik dalam mengelola bahan atau alat untuk menyelesaikan tugas atau proyek; e) Meningkatkan kolaborasi peserta didik khususnya pada Project Based Learning yang bersifat kelompok.

4. Keterampilan Berbicara dalam Bahasa Inggris

Pengertian bahasa menurut (Depkdiknas, 2005:3) “Bahasa pada hakikatnya adalah ucapan, pikiran dan perasaan manusia secara terarur yang, menggunakan bunyi sebagai media dalam berkomunikasi. Pengertian bahasa menurut Harun Rasyid, Mansyur dan Suratno (2009:126) "bahasa merupakan struktur dan makna yang bebas dari penggunaannya". Sedangkan arti bahasa menurut KBBI dalam (Hasan Alwi, 2002: 88) "bahasa dapat diartikan sebagai suatu sistem lambang bunyi atau suara arbirter, yang digunakan oleh seseorang atau masyarakat untuk bekerjasama, berinteraksi, dan mengidentifikasi diri dalam bentuk percakapan, berperilaku sopan dan santun".

Berdasarkan beberapa penegertian bahasa tersebut, maka dapat disimpulkan bahasa adalah suatu lambang-lambang nunyi suara yang digunakan untuk mengungkapkan perasaan dan pikiran ke dalam bahasa. Fungsi bahasa adalah mengungkapkan pikiran dan perasaan. Jadi tidak hanya ditujukan untuk bertukar pikiran saja, bahasapun memiliki peranan untuk mengungkapkan estetika, emosi manusia dalam interaksi sosial seperti mengekspresikan emosi marah, senang, dan sedih. Dalam hal ini mereka mengungkapkan perasaan dan bukan pikiran, oleh karena hal tersebut memiliki peranan sosial dan emosional, disamping itu bahasapun memiliki peran sebagai media untuk mengemukakan ide dan gagasan.

“Bahasa Inggris adalah bahasa asing yang sangat penting untuk diajarakan di dunia pendidikan yang bertujuan untuk menyerap dan mengembangkan ilmu pengetahuan, 
tekhnologi, seni budaya serta untuk mengetahui perkembangan hubungan antar bangsa (Dinny E: 2004)".

“Bahasa inggris merupakan mata pelajaran yang dapat mengembangkan keterampilan berkomunikasi secara lisan maupun tulisan dan dapat memahami, mengungkapkan perasaan, informasi, pikiran, serta mengembangkan ilmu pengetahuan, tekhnologi dan budaya “. (Depdiknas: 2004). Mata pelajaran bahasa inggris di sekolah menengah atas dapat berfungsi sebagai alat untuk mengembangkan siswa dalam bidang ilmu pengetahuan, tekhnologi dan seni. Setelah mereka menyelesaikan studi dan diharapkan merekapun dapat mengaplikasikannya dengan baik.

Bahasa Inggris dalam era globalisasi ini seringkali digunakan sebagai bahasa bisnis, bahasa pergaulan internasional, pengrekrutan karyawan di perusahaan berskala internasional. Oleh karena itu seiring berkembangnya zaman, baik siswa maupun guru dituntut untuk lebih mengenal bahasa asing atau bahasa inggris, bahkan bisa dikatakan bahwa penguasaan bahasa inggris sangat berpengaruh sebagai suatu faktor yang penting bagi suatu perusahaan asing dalam merekrut tenaga kerja. Pembelajaran diharapkan dapat membantu siswa lebih mengenal dirinya, budayanya, dan budaya orang lain, selain itu, pembelajaran bahasa, juga dapat membantu siswa dalam mengemukakan ide, gagasan dan perasaan, mampu berinteraksi dengan masyarakat asing, dan bahkan menemukan serta menggunakan kemampuan analitis dan imaginative yang ada dalam dirinya

Dalam Perencanaan pembelajaran di SMA Negeri 1 Cicalengka guru bahasas Inggris harus mempersiapkan dan menyusun program tahunan, program semester Kriteria Ketuntasan Minimal (KKM) dan Rencana Pelaksanaan Pembelajaran (RPP). Semua itu mengacu pada silabus yang sudah dibuat oleh tim dari kementrian pendidikan dan guru boleh mengembangkannya apabila dipelukan. Adapun buku sumber belajar yang sudah disediakan oleh pemerintah berdasarkan acuan dari silabus. Dengan demikian kurikulum tahun 2013 sebenanrnya memudahkan guru dalam merancang program pembelajaran. Program tahunan di SMA Negeri 1 Cicalengka berisi perhitungan minggu efektif untuk setiap bulan dari bulan Juni sampai dengan bulan Juli, kemudian uraian alokasi waktu untuk setiap bulan, dan uraian kegiatan minggu efektif dan minggu tidak efektif. Program 
tahunan dibuat oleh guru untuk merancang proses pembelajaran selama 2 semester, setelah itu dirancang program semester barulah dibuat Rencana Pelaksanaan Pembelajaran (RPP) yang mengacu pada silabus, dengan menggunakan metode project based learning. RPP yang dibuat oleh guru bahasa Inggris mengacu pada kurikulum tahun 2013.

Materi pelajaran yang diberikan ketika pelaksanaan observasi adalah Speaking dialog tentang Suggestion and opinion dalam kehidupan sehari-hari. Kalimat mana saja yang mengandung ungkapan dari materi Suggestion and opinion. Kegiatan pembelajaran di dalam kelas, guru menerapkan prinsip pembelajaran aktif, inovatif, kreatif, efektif, dan menyenangkan (PAIKEM). Langkah selanjutnya yang dilakukan oleh guru bahasa Inggris adalah membuat kriteria ketuntasan minimal (KKM). Hal ini agar tujuan pembelajaran bahasa Inggris memiliki acuan dalam pencapaian kompetensi yang dipersyaratkan dalam tujuan pembelajaran. Dalam menyusun KKM, guru bahasa Inggris harus memperhatikan tiga aspek yaitu kompleksitas, intake, daya dukung. Aspek kompeksitas yaitu tingkat kesulitan dan kerumitan materi dalam suatu kompetensi dasar. Aspek intake adalah kemampuan peserta didik dalam memahami materi pembelajaran. Aspek daya dukung berhubungan dengan kompensi guru dan sarana prasarana yang ada di sekPenilaian hasil pembelajaran bahasa Inggris menggunakan metode project based learning yang dilakukan oleh guru bahasa Inggris kelas XI, menganut prinsip penilaian authentic, yaitu penilaian sebenarnya yang mencakup penilaian pembelajaran termasuk aktivitas, perkembangan karakter dan pemahaan terhadap keterampilan tepatnya pada keterampilan berbicara (speaking). Proses penilaian dan pembelajaran mengunakan metode project based learning di sekolah tersbut adalah pengamatan. Pengamatan ini dilakukan oleh guru bahasa Inggris ketika peserta didik berada di tengah-tengah proses pembelajaran, mengajukan pertanyaan/permasalahan, merespon dan menjawab pertanyaan, berdiskusi dan mengerjakan tugas-tugas pembelajaran lainnya, baik di kelas maupun di luar kelas.

Masalah yang dihadapi oleh guru bahasa Inggris di sekolah yang diteliti dalam menerapkan manajemen pembelajaran melalui motede project based learning untuk meniingkatkan keterampilan berbicara bahasa Inggris yaitu keterbatasan kemampuan peserta didik, dan keterbatasan sarana-prasarana pendukung pembelajaran bahasa Inggris dengan manajemen pembelajaran melalaui project based learning. 
1. Kemampuan peserta didik: Setiap peserta didik memiliki karakter dan kemampuan yang berbeda-beda dalam merespon pembelajaran. Sebagian peserta didik mampu menyerap materi dengan cepat namun sebagian peserta didik lainnya butuh pengulangan materi dua hingga tiga kali sebelum benar-benar menguasai materi.

2. Keterbatasan sarana pendukung peserta didik : Setiap peserta didik memiliki latar belakang yang berbeda-beda mulai dari aspek pengetahuan, keterampilan hingga aspek aspek ekonomi, sehingga ada sebagian peserta didik yang merasa ada kesulitan dalam mengerjakan tugas berbasis proyek, yang mana akan banyak diperlukannya sarana pendukung pembelajaran. Seperti peserta didik yang sulit mengikuti materi karena di daerah ia tinggal jaringan internet masih sulit, atau peserta didik yang berada pada ekonomi tingkat menegah kebawah yang masih kesulitan karena adanya faktor himpitan ekonomi.

Manajemen pembelajaran melalui metode project based learning pada dasarnya memudahkan para guru dan siswa dalam mencapai kompetensi yang tinggi ditengah keterbatasan sarana dan kemampuan yang ada. Metode pembelajaran ini lebih menuntut kreativitas dan inovasi para guru sebagai pelaksana pembelajaran di dalam kelas dalam mengembangkan media, metode dan strategi pembelajaran agar tujuan pembelajaran dapat terwujud.

Adapun beberapa upaya-upaya yang dihadapi oleh guru dan peserta didik di SMA Negeri 1 Cicalengka, adalah sebagai berikut:

1) Melaksanakan kegiatan forum komunikasi Musyawarah Guru Mata Pelajaran (MGMP)

2) Meningkatkan pemahaman terhadap penyusunan rencana pelaksanaan pembelajaran termasuk memahami apa yang diperoleh dari kegiatan In house Training (IHT).

3) Melaksanakan diskusi antar sesama guru mata pelajaran sehingga terbina kerjasama untuk saling melengkapi kekurangan dalam merencanakan kegiatan pembelajaran.

4) Pembinaan dari pengawas dan kepala sekolah melalui In house Training (IHT).

5) Guru dalam pelaksanaan proses pembelajaran, senantiasa berusaha untuk meningkatkan motivasi diri dalam menciptakan proses pembelajaran yang efektif, menggunakan metode yang menyenangkan, menerapkan metode yang memudahkan peserta didik dalam mencapai kompetensi yang unggul peserta didik mendorong untuk selalu 
meningkatkan kemampuan berbahasa Inggris.

6) Selalu melaksanakan proses pembelajaran dengan berorientasi pada tujuan yang ingin dicapai dan pada akhirnya akan memberikan kepuasan bagi guru dan peserta didik.

\section{PENUTUP}

Berdasarkan hasil penelitian tentang manajemen pembelajaran menggunakan project based learning dalam meningkatakan keterampilan speaking di SMA Negeri 1 Cicalengka. Dapat disimpulkan bahwa kegiatan manajemen yang dilakuakan oleh guru bahasa Inggris kelas XI, meliputi perencanaan pembelajaran yang disusun oleh para guru, pelaksanaan pembelajaran yang melibatkan guru dan peserta didik serta penilaian bahasa Inggris, pada pelaksanaannya juga mengidentifikasi berbagai kendala yang dihadapi oleh guru dan peserta didik dalam menerapkan manajemen pembelajaran menggunakan metode project based learning dalam meningktakan keterampilan speaking peserta didik, serta berbagai upaya dilakukan untuk mengatasi kendala-kendala tersebut.

Berbagai temuan diperiksa keakuratannya dan kebenarannya, kemudian dianalisis, sehingga menghasilkan kesimpulan bahwa manjemen pembelejaran dengan menggunakan project based learning memungkinkan peserta didik untuk belajar bahasa Inggris lebih aktif, inovatif, kretif dan efektif. Selain itu baik peserta didik maupun guru merasa nyaman saat melaksankan pembelajaran bahasa Inggris yang variatif, tidak monoton dan proses penilaian lebih objektif meskipun penerapannya di lapangan masih dipengaruhi oleh faktor eksternal dan internal, seperti ketersediaan sarana prasarana, dukungan, sekolah, dan kemampuan guru yang optimal. Secara umum hasil penelitian ini, disimpulkan bahwa manajemen pembelajaran menggunakan project based learning dalam meningktkan keterampilan speaking, memberikan pengaruh yang signifikan terutama pada kelas XI.

\section{DAFTAR PUSTAKA}

Amaliah. (2020). Implementation Of Edpuzzle to Improve Students Analytical Thinking Skill in Narrative Text. Jurnal Prosidi, 14(1), 35-44.

Basri, H., \& Saebani, B. A. (2010). Ilmu pendidikan Islam. Bandung: Pustaka Setia.

Budiarto, I. D. (2020). Penggunaan Startegi Pembelajaran Filpped Classroom secara Daring Berbantuan Media Edpuzzle untuk Meningkatkan Pemahaman Materi Hukum Dasar 
Kimia Siswa Kelas X. Prosiding Seminar Nasional Kimia (SNK) 2020, 110. Surabaya: Jurusan Kimia FMIPA Universitas Negeri Surabaya.

Creswel, J. W. (2014). Research Design: Pendekatan Kualitatif, Kuantitatif, dan Mixed. Yogyakarta: Pustaka Pelajar.

Hergenhahn, B. R., \& Olson, M. (2008). Theories of Learning. Jakarta: Kencana Prenada Media Group.

Hikmawati, F. (2019). Metodologi Penelitian. Depok: PT RajaGrafindo Persada.

Margono. (1997). Metodologi Penelitian Pendidikan. Jakarta: Rineka Cipta.

Matlin, M. W. (2009). Cognitive Psychology. Denver: John Wiley \& Sons.

Moleong, L. J. (2017). Metodologi Penelitian Kualitatif. Jakarta: PT Remaja Rosdakarya.

Nurmila, N. (2020). Paradigma Positivisme dan Postpositivisme. Bandung.

Schunk, D. H. (2012). Learning Theories. Yogyakarta: Pustaka Pelajar.

Sukmadinata, N. S. (2012). Metode Penelitian Pendidikan. Bandung: PT Remaja Rosdakarya.

Syah, M. (1995). Psikologi Pendidikan Suatu Pendekatan Baru. Bandung: PT Remaja Rosdakarya.

Uno, H. B. (2009). Model Pembelajaran: Menciptakan Pro Ahmad, A dan A . Rohani. 1995.

Pengelolaan Pengajaran. Jakarta : Jakarta: Rineka Cipta.

Ambarita, Alben. 2006. Manajemen Pembelajaran. Jakarta: Departemen Pendidikan Nasional.

Arikunto, 2006. Dasar - Dasar Evaluasi Pendidikan. Jakarta: PT Rineka Cipta. 2008. Penelitian Tindakan Kelas. Jakarta: Bumi Aksara.

Ausubel David P., Joseph D. Novak, and Helen Hanesian. 1978. Educational Psychology, New York: Halt, Renehart and Winson.

Barlian, Ujang Cepi.2016. Manajemen Strategi Konsep dan Implementasi.Bandung: Khalifa Insan Press.

Bruner, Jerome S., 1973. The Relevance of Education. New York: The Norton Library.

Brown, Doguglas H. 2004. Language Assessment : Principles and Classroom Practices. New York : Pearson Education.

2001. Teaching by Principles. New York: Addition Wesley Longman.

Darwan Wawan. 2017. Tsesis Model Pembelajaran Karakter di Lingkungan Sekolah Berbasi Budaya.

Dimyati dan Mudjiono. 1999. Belajar dan Pembelajaran. Jakarta: Rineka Cipta, h. 250-251.

Diningsih, Nining. 2020. Manajemen Berbasis Sekolah. Sumedang/Bandung: $\quad$ Alqaprint Jatinangor.

Johnson, Elaine B. 2009. Contextual teaching and learning: menjadikan kegiatan belajar mengajar mengasyikan dan bermakna. Bandung: Mizan Learning

Center.

Moleong, Lexy. J. 2004. Metode Penelitian Kualitatif. Bandung : Bandung: Remaja Rosdakarya. . 2011. Metodologi Penelitian Kualitatif Edisi Revisi: Bandung : Remaja Rosdakarya.

Nur, Agustiar Syah.2001. Perbandingan Sistem Pendidikan 15 Negara. Edisi Pertama. Bandung: Lubuk Agung.

Sanjaya, Wina. 2007. Strategi Pembelajaran Berorientasi Standar Proses Pendidikan. Jakarta: Kencana Prenada Media Group.

Sugiyono. 2012. Metode Penelitian Kuantitatif Kualitatif dan REB. Bandung: Alfabeta.

Sa'ud, Udin Syaefudin dan Abin Syamsudin. 2018. Perencanaan Pendidikan Suatu Pendekataan Komprehensif. Bandung : Remaja Rosdakarya.

Nurhayati Tesna. 2018. Tesis Manajemen Model Problem Instruction untuk Meningkatkan mutu 


\section{Pembelajaran.}

Winarni, Hj. Wiwin. 2009. Disertasi Model Manajemen Sekolah Unggulan.

Jurnal :

Diningsih, Nining dkk.2018. Jurnal Peteka. Aqaprint Jatinangor.

Rizki, Wa ode Tika Jurnal. Jurnal Peningkatan Kemampuan Berbicara dalam Bahasa Inggris Melalui Storytelling Pada Siswa SMK Negeri 3 Kota Sorong.

Dokumen:

Permendiknas. No. 41 Tahun 2007. Tentang Standar Proses

Permendiknas. No. 20 Tahun 2007. Tentang Standar Penilaian

Permendiknas. No. 19 Tahun 2007. Tentang Standar Pengelolaan Pendidikan

Undang - Undang RI. No. 20 Tahun 2003. Tentang Standar Sistem Pendidikan Nasional

Undang-Undang RI.. No. 14 Tahun 2005. Tentang Guru dan Dosen Undang -Undang RI. No.19 Tahun 2005. Tentang Standar Pendidikan Nasional.ses Belajar Mengajar yang Kreatif dan Efektif. Jakarta: Bumi Aksara.

Uys, W. F., \& Chigona, W. (2020). Evaluating Undergraduate Studens' Self Directed Learning Experiences During Research-Based Learning'. in E. Mentz \& R. Bailey (eds), Self-directed learning research and its impact on educational practice (Vol. 3; E. Mentz \& R. Bailey, eds.). Retrieved from https://books.aosis.co.za/index.php/ob/catalog/book/206 